\title{
Blinatumomab Regimen
}

National Cancer Institute

\section{Source}

National Cancer Institute. Blinatumomab Regimen. NCI Thesaurus. Code C160000.

An immunotherapy regimen consisting of blinatumomab that may be used in the treatment of acute lymphoblastic leukemia (ALL). 